\title{
BORON ALTERS CATION EXCHANGE PROPERTIES OF CORN ROOTS BUT DOES NOT DECREASE ALUMINUM TOXICITY
}

\author{
BORO ALTERA AS PROPRIEDADES DE TROCA CATIÔNICA DA RAIZ DE MILHO, \\ MAS NÃO DIMINUI A TOXIDEZ POR ALUMÍNIO
}

\section{Julierme Zimmer BARBOSA ${ }^{1}$; Antonio Carlos Vargas MOTTA ${ }^{2}$; Rangel CONSALTER ${ }^{3}$; Volnei PAULETTI ${ }^{2}$}

1. Ph.D. Professor, Department of Agronomy, Ingá University Center (Uningá), Maringá, PR, Brazil. barbosajz@ yahoo.com.br; 2. Ph.D. Professor, Department of Soils and Agricultural Engineering, Federal University of Paraná - UFPR, Curitiba, PR, Brazil; 3. Ph.D. Soil Science, Federal University of Paraná - UFPR, Curitiba, PR, Brazil.

\begin{abstract}
Most studies that have registered amelioration of Al toxicity due to root cation exchange capacity (CEC) decrease with B application were conducted using eudicotyledonous species (high root CEC). However, the effect of $\mathrm{B} / \mathrm{Al}$ interaction on the root CEC values in species with low root CEC such as corn (Zea mays L.) has been understudied. Thus, this study aimed to: (1) verify if B decreases root CEC and if it benefits the growth and nutrient uptake in corn plants under Al toxicity; and (2) verify which method of root CEC analysis better differentiates the effects of B and Al. Corn seedlings were grown in complete nutrient solution with the following treatments: 0,50 , and $200 \mu \mathrm{M}$ of B versus 0 and $300 \mu \mathrm{M}$ of Al. Root attributes showed correlations with nutrient depletion from the nutrient solution, but nutrient depletion generally varied with transpiration in two depletion tests. The addition of $\mathrm{B}$ or $\mathrm{Al}$ in nutrient solution decreased root CEC; however, B failed to decrease Al toxicity in corn plants. The four methods used to determine CEC of corn roots had contrasting results, particularly with respect to the effect of B in the presence of $\mathrm{Al}$.
\end{abstract}

KEYWORDS: Metal sorption. Ionic stress. Root traits. Plant methods.

\section{INTRODUCTION}

In acid soils, $\mathrm{Al}$ toxicity is first detected in root system of sensitive species, usually with a growth decrease. Due to rhizotoxicity, absorption of nutrients and water is limited, impairing plant growth (KOCHIAN et al., 2015). Although $\mathrm{Al}$ is strongly retained in root tissue, toxic levels can reach the shoot in some crops (HORST et al., 2010). On the other hand, B deficiency induces a negative impact on meristematic tissues, which impairs growth of underground and aerial tissues due to thickening and weakening of cell walls. In general, the largest fraction of $\mathrm{B}$ in plants is associated with cell walls (GOLDBACH; WIMMER, 2007); however, B toxicity can affect roots and shoots (BARBOSA et al., 2013; ÇATAV et al., 2018).

Symptoms of Al toxicity and B deficiency have aroused interest concerning $\mathrm{B} / \mathrm{Al}$ interactions in plants. LeNoble et al. (1996) reported decreased Al toxicity when B was added at levels above the normal range. Subsequently, different mechanisms have been associated with the amelioration of $\mathrm{Al}$ toxicity, such as B effects on ascorbate metabolism (LUBASZEWSKI; BLEVIS, 1996), synthesis of antioxidants (RIAZ et al., 2018), and reducing root cation exchange capacity (CEC) (HORST et al., 2010).

Root CEC occurs due to the presence of negative charges in cell walls and plasma membranes, the two main sources of negative electrical charge of roots (WHITE, 2012; GUIGUES et al., 2014). Root cation binding properties have been assessed in terms of acquisition of nutrients and toxic elements (CEZAR et al., 2015; BARBOSA et al., 2017). In these studies, different analytical methods have been used in root CEC determinations.

Studies investigating the amelioration of $\mathrm{Al}$ toxicity due to root CEC decreases by B application have used eudicotyledonous species (high root CEC) (STASS et al., 2007; YU et al., 2008; HORST et al., 2010). However, the effect of $\mathrm{B} / \mathrm{Al}$ interaction on root CEC values in species with low root CEC such as monocotyledonous corn is not well known. Thus, this study aimed to: (1) verify if B decreases root CEC and benefits growth and nutrient uptake in corn plants under Al toxicity; and (2) verify which method for root CEC analysis better differentiates the effects of $\mathrm{B}$ and $\mathrm{Al}$.

\section{MATERIAL AND METHODS}

The experiment was conducted in a plastic greenhouse (ambient light and partial temperature control) in Curitiba, Paraná State, Brazil. Due to lack of light control, it is important to state that the experiment was conducted during a period (November 2012) when cultivation of corn is recommended in this region. Greenhouse 
temperature control consisted of air extractors and an air humidifying system that automatically activates when temperature reach $28^{\circ} \mathrm{C}$, and remaining operating until the temperature drops below $28^{\circ} \mathrm{C}$.

Corn seeds (single-cross hybrid DKB 350) were germinated in washed sand moistened with deionized water. Seedlings (4 seedlings) at three days of emergence were fixed in expanded polystyrene and transferred to plastic pots containing 1.5 L Hoagland solution (continuously aerated and without addition of $\mathrm{B}$ ) with up to $1 / 5$ of the solution at $\mathrm{pH} 4.5$. One day after transplanting (DAT), 0, 50, and $200 \mu \mathrm{M} \mathrm{B}\left(\mathrm{H}_{3} \mathrm{BO}_{3}\right) \times 0$ and 300 $\mu \mathrm{M} \mathrm{Al}\left(\mathrm{AlCl}_{3}\right)$ were added to treatment nutrient solutions in a factorial design with four replicates per treatment. The average experimental temperature in the greenhouse was $26^{\circ} \mathrm{C}$.

After 12 DAT, two pots without plants were added. The pots were weighed with and without nutrient solution. Aliquots of $30 \mathrm{~mL}$ of solution (which reflected additions of $\mathrm{B}$ and $\mathrm{Al}$ ) were collected at time zero and after 24 hours (Test I); these aliquots were filtered on filter paper and packaged in plastic bottles for storage at $4^{\circ} \mathrm{C}$. After the initial 24 hour test, pots were weighed again. Subsequently, the nutrient solution was replaced in the absence of B and Al treatments (Test II); aliquot collections were conducted as described above. By difference in mass of liquid in the pots containing plants (evapotranspiration) and those without plants (evaporation), transpiration data were obtained for each test. For the nutrient solution we determined: $\mathrm{NH}_{4}{ }^{+}$- spectrometry UV/VIS (phenate) (Bel Photonics, SP2000); K - flame emission spectrometry (Digimed, MD-62); and $\mathrm{Ca}, \mathrm{Mg}, \mathrm{Fe}$, $\mathrm{Mn}, \mathrm{Cu}$, and $\mathrm{Zn} \mathrm{-} \mathrm{atomic} \mathrm{emission} \mathrm{spectrometry}$ (Varian, AA240FS). Based on the difference between the initial nutrient content and the final content, nutrient depletion over a 24 hour period was determined.

At 14 DAT, corn plants were removed from the nutrient solution, and plants were then separated into roots and shoots. The roots were rinsed in deionized water (15 second immersion), dried on paper towels, and mass determined. The root system from one plant per experimental unit was stored in $60 \%$ ethanol. The roots stored in ethanol were analyzed using 2-D WinRHIZO ${ }^{\circledR}$ equipment and values attributes of length, surface area, and volume were determined. The other roots and shoots of plants were subjected to drying in a forced ventilation oven at $65^{\circ} \mathrm{C}$ for $72 \mathrm{~h}$. The dry matter of corn roots and shoots was then determined.

Dry roots were ground in a porcelain mortar and analyzed for CEC by different methodologies (Table 1). The remaining root and shoot tissues were ground with a Wiley mill, passed through a 1 $\mathrm{mm}$ sieve, and subjected to dry digestion (MARTINS; REISSMANN, 2007). The B and Al concentrations were determined by optical emission spectrometry with inductively coupled plasma (Varian 720-ES).

Table 1. Description of sequential steps for analysis of root cation exchange capacity (CEC).

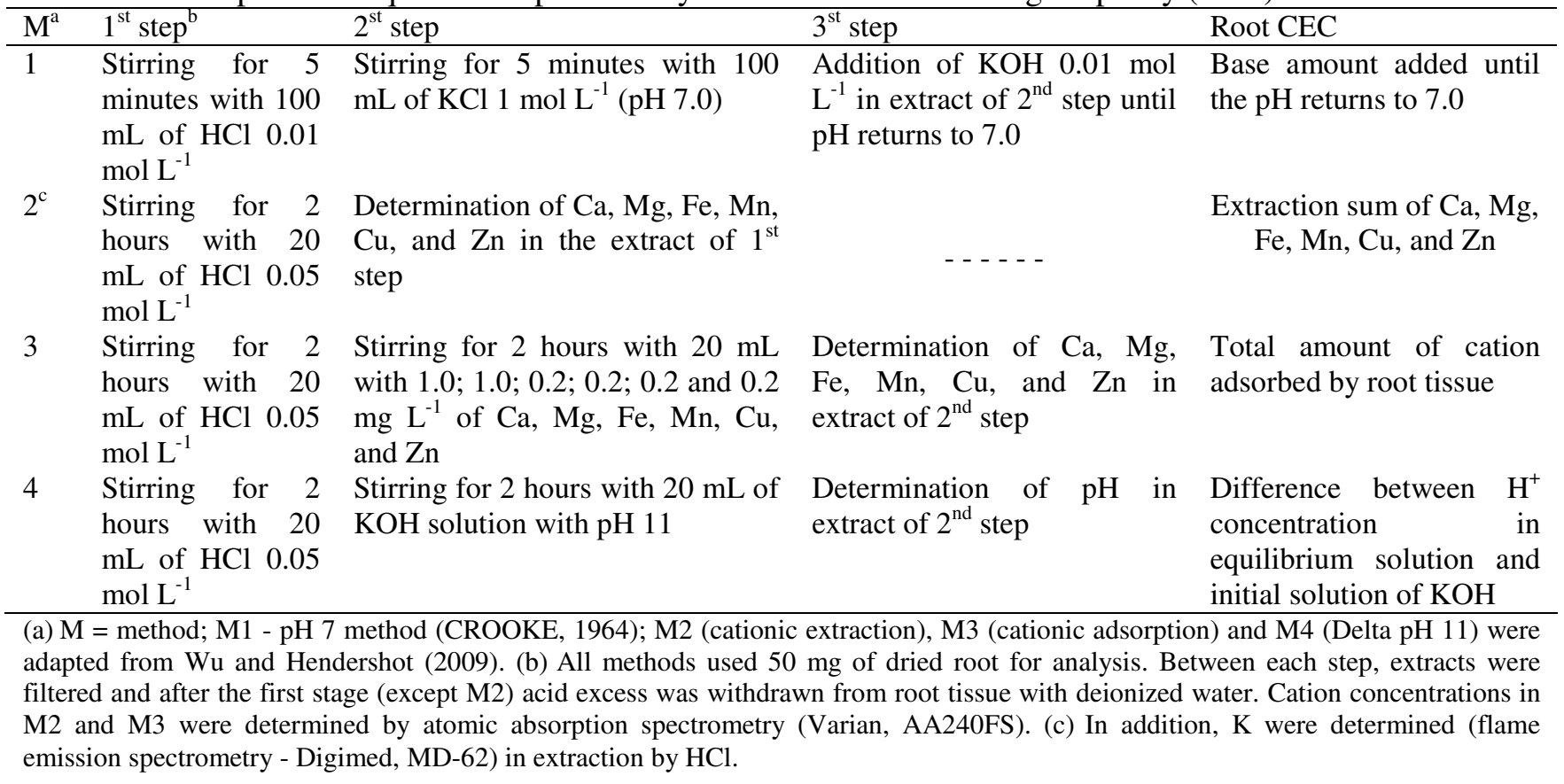


Data were submitted to analysis of variance following a completely randomized design with a $3 \times 2$ factorial arrangement (3 levels of B x 2 levels of $\mathrm{Al}$ ) with four replications. For data analysis, Tukey's test and Pearson correlations were used. All tests were performed at the $5 \%$ significance level.
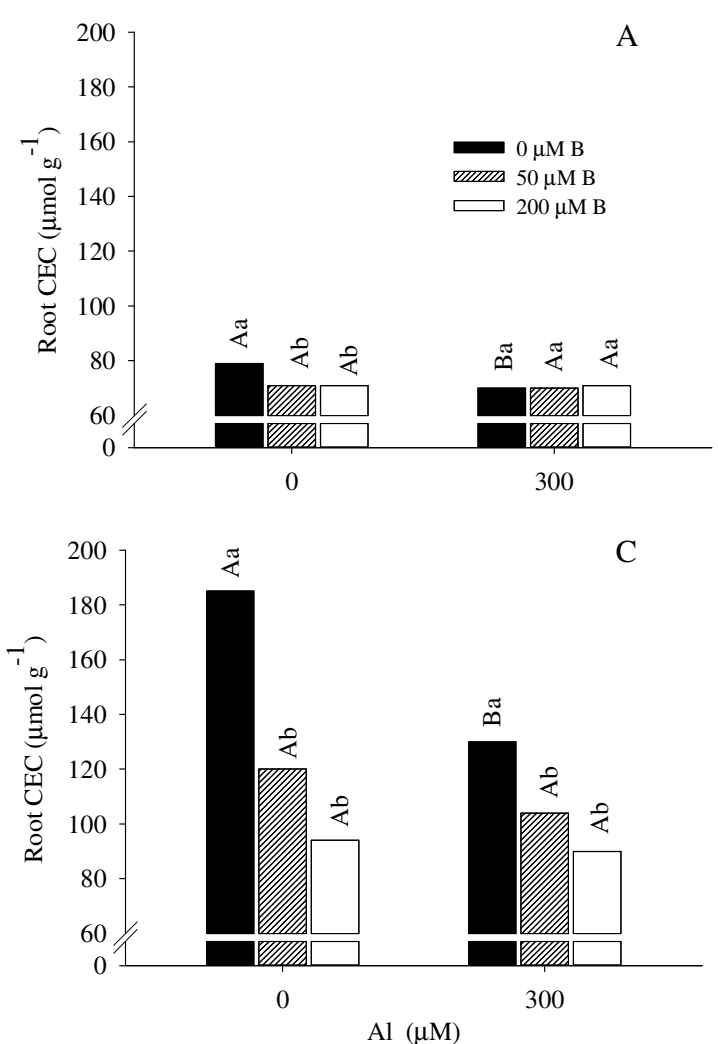

Figure 1. Root cation exchange capacity (CEC) in corn grown in nutrient solution with different $\mathrm{B}$ and $\mathrm{Al}$ levels. A, B, C and D represent Methods 1, 2, 3, and 4, respectively. For each B level (Al effect), averages followed by different uppercase letters and for each Al level (B effect), averages followed by the different lowercase letters represent differences by the Tukey test $(\mathrm{p}<0.05)$.

In treatments without addition of $\mathrm{Al}, \mathrm{Ca}$, and $\mathrm{Mg}$, macronutrients were extracted in greater quantity from root tissue when B was not applied in solution, whereas this behavior did not occur in the presence of $\mathrm{Al}$ (Table 2). These results are due to reduced root $\mathrm{CEC}$ in the presence of $\mathrm{Al}$, thus, the effect of $\mathrm{B}$ on the amount of $\mathrm{Ca}$ and $\mathrm{Mg}$ extracted by roots had probably been minimized. The amount of $\mathrm{Fe}$ extracted from roots increased with $\mathrm{B}$ addition, however, extracted amounts of other micronutrients ( $\mathrm{Mn}, \mathrm{Cu}, \mathrm{Zn}$ ) had no impact on $\mathrm{B}$ (Table 2). In the absence of $\mathrm{Al}$, the adsorption of $\mathrm{Ca}, \mathrm{Mg}, \mathrm{Fe}, \mathrm{Mn}, \mathrm{Zn}$, and $\mathrm{Cu}$ decreased with $\mathrm{B}$ addition to the nutrient solution. However, in the presence of $\mathrm{Al}$, the discrimination of $\mathrm{B}$ levels was repeated only for the adsorption of $\mathrm{Fe}$ and $\mathrm{Cu}$ (Table 2).
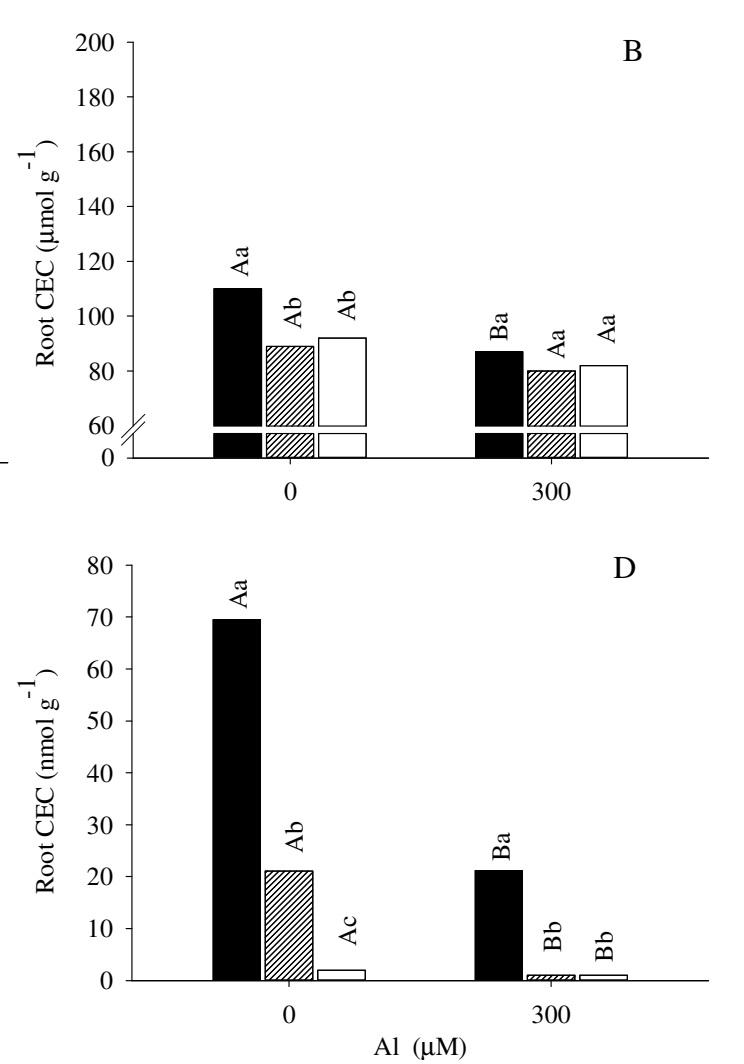

\section{RESULTS}

Application of $\mathrm{B}$ and $\mathrm{Al}$ in nutrient solution caused decreases in corn root CEC. However, among the four methods tested some differences were noted (Figure 1). 
Table 2. Extraction and adsorption of nutrients in root of corn grown in nutrient solution with B and Al levels.

\begin{tabular}{|c|c|c|c|c|c|c|c|}
\hline \multirow[t]{2}{*}{ Nutrient } & \multirow{2}{*}{$\begin{array}{l}\mathrm{Al}(\mu \mathrm{M}) \\
\mathrm{B}(\mu \mathrm{M})\end{array}$} & \multicolumn{3}{|c|}{0} & \multicolumn{3}{|c|}{300} \\
\hline & & 0 & 50 & 200 & 0 & 50 & 200 \\
\hline & & \multicolumn{6}{|c|}{-------------------------- g kg } \\
\hline & & \multicolumn{6}{|c|}{ Extraction } \\
\hline $\mathrm{K}$ & & $17.8 \mathrm{Ab}$ & $21.5 \mathrm{Aa}$ & 19.0 Aab & $8.81 \mathrm{Ba}$ & $8.65 \mathrm{Ba}$ & $8.02 \mathrm{Ba}$ \\
\hline $\mathrm{Ca}$ & & $2.32 \mathrm{Aa}$ & $1.62 \mathrm{Ab}$ & $1.81 \mathrm{Ab}$ & $1.86 \mathrm{Ba}$ & $1.72 \mathrm{Aa}$ & $1.77 \mathrm{Aa}$ \\
\hline $\mathrm{Mg}$ & & $0.97 \mathrm{Aa}$ & $0.82 \mathrm{Aab}$ & $0.77 \mathrm{Ab}$ & $0.68 \mathrm{Ba}$ & $0.60 \mathrm{Ba}$ & $0.62 \mathrm{Ba}$ \\
\hline $\mathrm{Fe}$ & & $0.23 \mathrm{Bb}$ & $0.26 \mathrm{Bab}$ & $0.31 \mathrm{Aa}$ & $0.33 \mathrm{Aa}$ & $0.34 \mathrm{Aa}$ & $0.35 \mathrm{Aa}$ \\
\hline $\mathrm{Mn}$ & & $0.23 \mathrm{~A}$ & $0.27 \mathrm{~A}$ & $0.23 \mathrm{~A}$ & $0.15 \mathrm{~B}$ & $0.16 \mathrm{~B}$ & $0.17 \mathrm{~B}$ \\
\hline $\mathrm{Cu}$ & & $0.13 \mathrm{~A}$ & $0.16 \mathrm{~A}$ & $0.15 \mathrm{~A}$ & $0.11 \mathrm{~B}$ & $0.10 \mathrm{~B}$ & $0.11 \mathrm{~B}$ \\
\hline \multirow[t]{2}{*}{$\mathrm{Zn}$} & & $0.15 \mathrm{~A}$ & $0.16 \mathrm{~A}$ & $0.16 \mathrm{~A}$ & $0.12 \mathrm{~B}$ & $0.13 \mathrm{~B}$ & $0.11 \mathrm{~B}$ \\
\hline & & \multicolumn{6}{|c|}{ Adsorption } \\
\hline $\mathrm{Ca}$ & & $1.91 \mathrm{Aa}$ & $1.05 \mathrm{Ab}$ & $1.07 \mathrm{Ab}$ & $1.01 \mathrm{Ba}$ & $1.05 \mathrm{Aa}$ & $1.04 \mathrm{Aa}$ \\
\hline $\mathrm{Mg}$ & & $1.29 \mathrm{Aa}$ & $0.71 \mathrm{Ab}$ & $0.98 \mathrm{Aab}$ & $0.74 \mathrm{Ba}$ & $0.84 \mathrm{Aa}$ & $1.04 \mathrm{Aa}$ \\
\hline $\mathrm{Fe}$ & & $2.78 \mathrm{Aa}$ & $2.05 \mathrm{Ab}$ & $0.58 \mathrm{Ac}$ & $2.30 \mathrm{Ba}$ & $1.12 \mathrm{Bb}$ & $0.63 \mathrm{Ab}$ \\
\hline Mn & & $0.79 \mathrm{a}$ & $0.68 \mathrm{a}$ & $0.31 \mathrm{~b}$ & $0.67 \mathrm{a}$ & $0.52 \mathrm{a}$ & $0.18 \mathrm{~b}$ \\
\hline $\mathrm{Cu}$ & & 1.18 Aa & $0.81 \mathrm{Ab}$ & $0.40 \mathrm{Ac}$ & $0.93 \mathrm{Ba}$ & $0.57 \mathrm{Ab}$ & $0.31 \mathrm{Ab}$ \\
\hline $\mathrm{Zn}$ & & $0.47 \mathrm{Aa}$ & $0.45 \mathrm{Aa}$ & $0.27 \mathrm{Ab}$ & $0.40 \mathrm{Aa}$ & $0.31 \mathrm{Aa}$ & $0.27 \mathrm{Aa}$ \\
\hline
\end{tabular}

For each $\mathrm{B}$ level (Al effect), averages followed by the different uppercase letters and, for each $\mathrm{Al}$ level (B effect), averages followed by the different lowercase letters present difference by Tukey test $(\mathrm{p}<0.05)$.
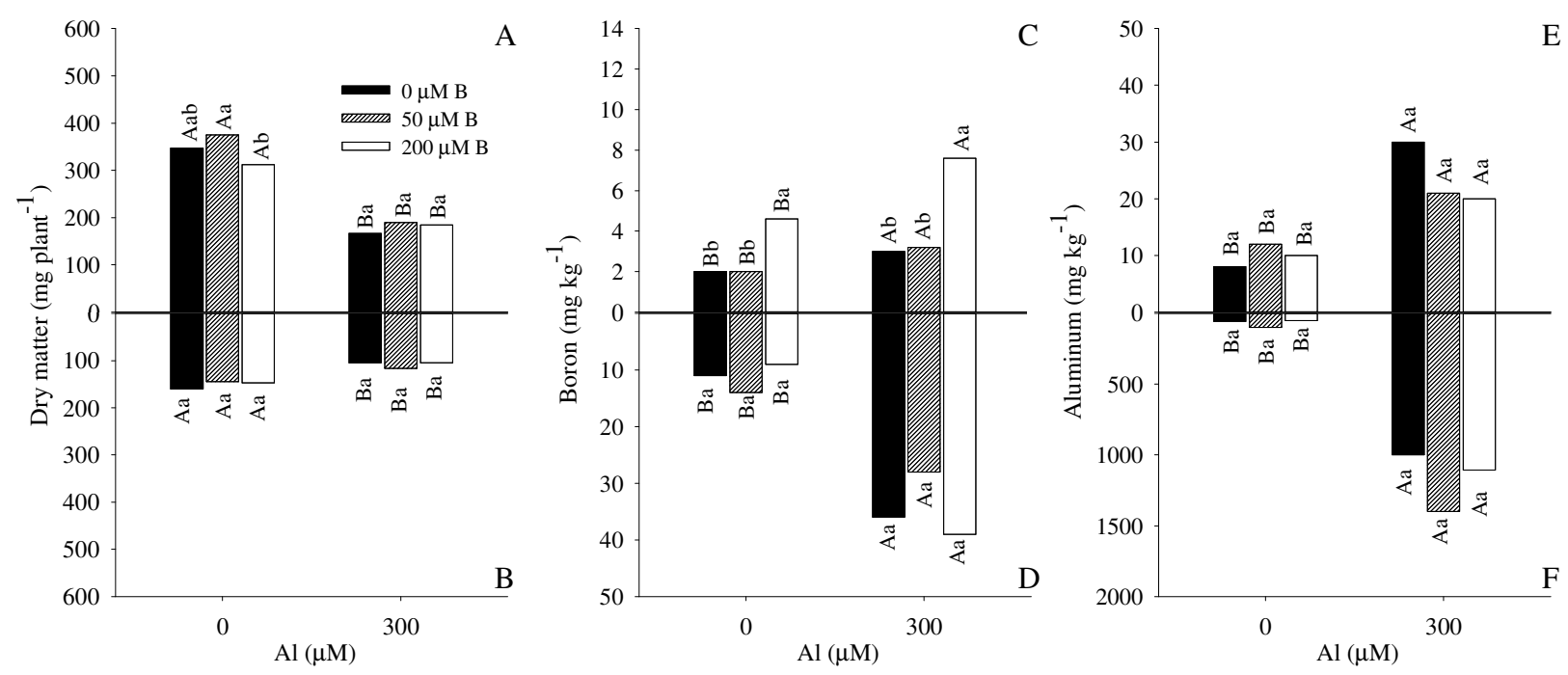

Figure 2. Dry matter, concentration of $\mathrm{B}$ and $\mathrm{Al}$ in corn grown in nutrient solution with $\mathrm{B}$ and $\mathrm{Al}$ levels. Shoots $(\mathrm{A}, \mathrm{C}, \mathrm{E})$ and roots $(\mathrm{B}, \mathrm{D}, \mathrm{F})$. For each B level (Al effect), averages followed by the different uppercase letters and, for each $\mathrm{Al}$ level (B effect), averages followed by the different lowercase letters present differences by Tukey test $(\mathrm{p}<0.05)$.

Table 3. Root length, surface area, and volume of corn grown in nutrient solution with B and Al levels.

\begin{tabular}{lccccccc}
\hline Root & $\mathrm{Al}(\mu \mathrm{M})$ & \multicolumn{3}{c}{0} & 300 \\
attributes & $\mathrm{B}(\mu \mathrm{M})$ & 0 & 50 & 200 & 0 & 50 & 200 \\
\hline Length & & $204 \mathrm{~A}$ & $190 \mathrm{~A}$ & $206 \mathrm{~A}$ & $98 \mathrm{~B}$ & $112 \mathrm{~B}$ & $97 \mathrm{~B}$ \\
Surface area & & $54 \mathrm{~A}$ & $52 \mathrm{~A}$ & $60 \mathrm{~A}$ & $30 \mathrm{~B}$ & $36 \mathrm{~B}$ & $30 \mathrm{~B}$ \\
Volume & $16 \mathrm{~A}$ & $18 \mathrm{~A}$ & $21 \mathrm{~A}$ & $10 \mathrm{~B}$ & $13 \mathrm{~B}$ & $10 \mathrm{~B}$ \\
\hline
\end{tabular}

For each B level (Al effect), averages followed by the different uppercase letters present difference by Tukey test $(\mathrm{p}<0.05)$. B levels did not present differences by Tukey test. Length, $\mathrm{cm}$. Surface area, $\mathrm{cm}^{2}$; Volume, $\mathrm{mm}^{3}$. 
In Test I, there was a decrease in $\mathrm{NH}_{4}{ }^{+}, \mathrm{K}$, and $\mathrm{Zn}$ depletion from the nutrient solution and in corn transpiration under $\mathrm{Al}$ toxicity. In Test II, lower $\mathrm{NH}_{4}^{+}$and $\mathrm{K}$ depletion from nutrient solution for corn under $\mathrm{Al}$ toxicity was recorded, while there was a greater depletion of $\mathrm{Cu}$ from nutrient solution in plants grown without $\mathrm{Al}$ and with $\mathrm{B}$ presence (50 $\mu \mathrm{M})$. For transpiration in Test II, the Al toxicity decreased values only in the absence and addition of
B $(50 \mu \mathrm{M})($ Table 4). Correlations among nutrient depletion and corn plant attributes indicated variations considering the two depletion tests (Figure 3).

In general, depletion of $\mathrm{NH}_{4}{ }^{+}, \mathrm{K}, \mathrm{Ca}, \mathrm{Fe}, \mathrm{Mn}$, $\mathrm{Zn}$, and $\mathrm{Cu}$ (Test I), and $\mathrm{NH}_{4}{ }^{+}, \mathrm{K}, \mathrm{Mn}, \mathrm{Zn}$, and $\mathrm{Cu}$ (Test II) from nutrient solution, correlated (positive) mainly with transpiration.

Table 4. Nutrient depletion and transpiration $(\mathrm{T})$ of corn grown in nutrient solution with $\mathrm{B}(0,50$, and $200 \mu \mathrm{M})$ and $\mathrm{Al}(0$ and $300 \mu \mathrm{M})$ levels .

\begin{tabular}{|c|c|c|c|c|c|c|c|}
\hline \multirow{2}{*}{ Variables $^{\mathrm{b}}$} & $\mathrm{Al}(\mu \mathrm{M})$ & \multicolumn{3}{|c|}{0} & \multicolumn{3}{|c|}{300} \\
\hline & $\mathrm{B}(\mu \mathrm{M})$ & 0 & 50 & 200 & 0 & 50 & 200 \\
\hline & & \multicolumn{6}{|c|}{ Test $I^{\mathrm{c}}$} \\
\hline & & \multicolumn{6}{|c|}{--- $\mu \mathrm{mol} \mathrm{g}{ }^{-1}$ root fresh matter --- } \\
\hline K & & $49.1 \mathrm{~A}$ & $53.7 \mathrm{~A}$ & $51.4 \mathrm{~A}$ & $39.5 \mathrm{~B}$ & $39.8 \mathrm{~B}$ & $42.6 \mathrm{~B}$ \\
\hline $\mathrm{NH}_{4}^{+}$ & & $18.4 \mathrm{~A}$ & $18.8 \mathrm{~A}$ & $18.4 \mathrm{~A}$ & $17.3 \mathrm{~B}$ & $17.2 \mathrm{~B}$ & $17.4 \mathrm{~B}$ \\
\hline $\mathrm{Ca}$ & & 15.8 & 17.2 & 16.0 & 15.1 & 17.4 & 16.1 \\
\hline $\mathrm{Mg}$ & & 11.3 & 13.4 & 13.0 & 12.0 & 12.2 & 12.6 \\
\hline $\mathrm{Fe}$ & & 7.35 & 7.38 & 7.28 & 7.02 & 7.16 & 6.92 \\
\hline $\mathrm{Mn}$ & & 7.60 & 7.25 & 7.10 & 6.65 & 7.57 & 7.13 \\
\hline $\mathrm{Cu}$ & & 2.02 & 2.02 & 1.86 & 1.93 & 1.61 & 1.11 \\
\hline \multirow[t]{2}{*}{$\mathrm{Zn}$} & & $1.70 \mathrm{~A}$ & $1.73 \mathrm{~A}$ & $1.66 \mathrm{~A}$ & $1.28 \mathrm{~B}$ & $1.47 \mathrm{~B}$ & $1.36 \mathrm{~B}$ \\
\hline & & & & $----m$ & $\mathrm{nt}^{-1}------$ & ------ & \\
\hline \multirow[t]{3}{*}{ Transpiration } & & $28.7 \mathrm{Ab}$ & $39.3 \mathrm{Aa}$ & $19.8 \mathrm{Ab}$ & $18.7 \mathrm{Ba}$ & $16.7 \mathrm{Ba}$ & $13.7 \mathrm{Ba}$ \\
\hline & & \multicolumn{6}{|c|}{ Test II } \\
\hline & & & \multicolumn{5}{|c|}{-- $\mu \mathrm{mol} \mathrm{g}{ }^{-1}$ root fresh matter -- } \\
\hline $\mathrm{K}$ & & 40.2 & 53.6 & 49.1 & 49.3 & 48.9 & 51.6 \\
\hline $\mathrm{NH}_{4}^{+}$ & & 17.8 Aa & 18.1 Aa & $18.2 \mathrm{Aa}$ & $16.3 \mathrm{Ba}$ & $16.7 \mathrm{Ba}$ & $17.5 \mathrm{Aa}$ \\
\hline $\mathrm{Ca}$ & & 13.9 & 13.0 & 13.5 & 12.8 & 13.5 & 13.0 \\
\hline $\mathrm{Mg}$ & & 12.6 & 13.3 & 11.8 & 12.9 & 14.0 & 12.2 \\
\hline $\mathrm{Fe}$ & & 7.73 & 7.30 & 7.44 & 6.25 & 6.04 & 6.50 \\
\hline $\mathrm{Mn}$ & & 6.20 & 6.79 & 5.90 & 5.90 & 6.29 & 5.62 \\
\hline $\mathrm{Cu}$ & & $2.66 \mathrm{Ab}$ & $2.95 \mathrm{Aa}$ & $2.51 \mathrm{Ab}$ & $2.64 \mathrm{Aa}$ & $2.70 \mathrm{Aa}$ & $2.59 \mathrm{Aa}$ \\
\hline $\mathrm{Zn}$ & & 1.77 & 1.77 & 1.54 & 1.67 & 1.58 & 1.58 \\
\hline Transpiration & & $20.6 \mathrm{Aa}$ & $22.6 \mathrm{Aa}$ & $15.6 \mathrm{Aa}$ & $7.5 \mathrm{Ba}$ & $8.0 \mathrm{Ba}$ & $12.9 \mathrm{Aa}$ \\
\hline
\end{tabular}

(a) For each $\mathrm{B}$ level (Al effect), averages followed by the different uppercase letters and, for each $\mathrm{Al}$ level (B effect), averages followed by the different lowercase letters present difference by Tukey test $(\mathrm{p}<0.05)$. (b) Variables. (c) Test I: nutrient solution with B and Al;

Test II: nutrient solution without B and Al. 

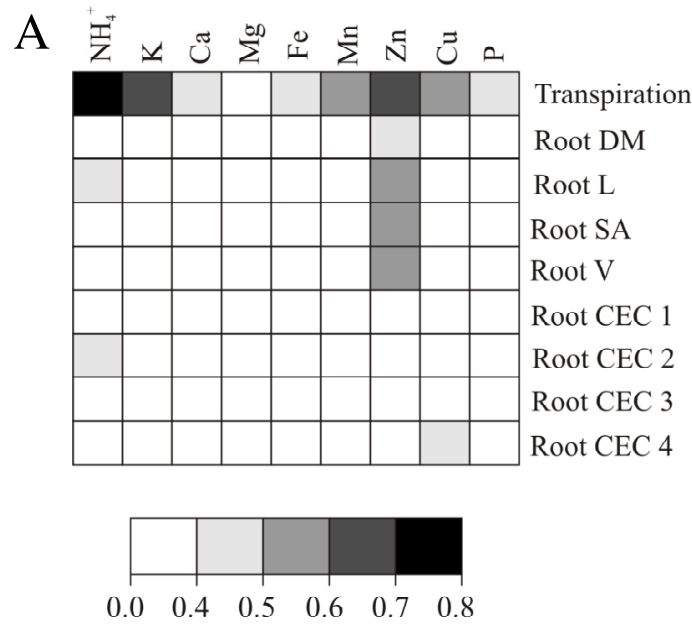
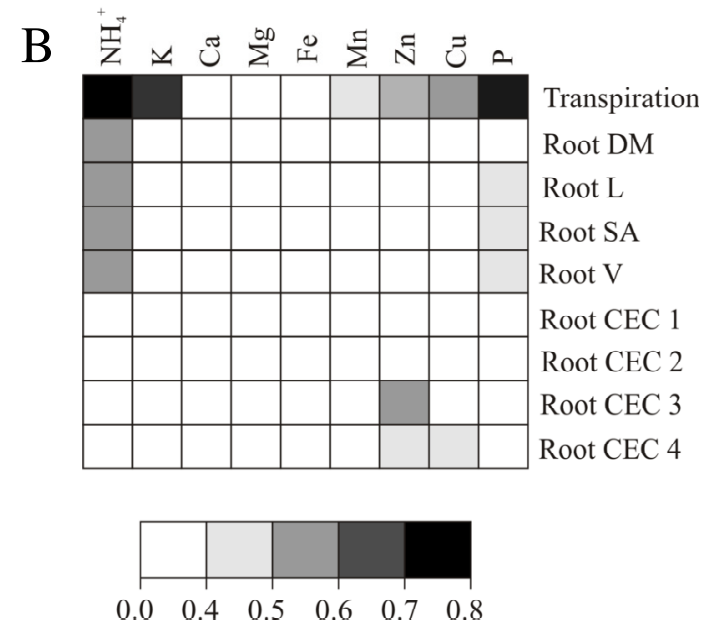

Figure 3. Pearson correlations $(\mathrm{p}<0.05)$ between nutrient depletion and attributes of corn grown in nutrient solution with B and Al levels (A: Test I; B: Test II). CEC of roots 1, 2, 3, and 4 correspond to the methods $\mathrm{KCl} \mathrm{pH}$ 7, cationic extraction, cationic adsorption, and Delta $\mathrm{pH} 11$, respectively. Scales indicate the value of the correlation coefficient.

\section{DISCUSSION}

Decreases in root CEC by adding B (Figure 1) corroborates the results observed by Stass et al. (2007) for cell walls in root tips of bean. The authors found that addition of $50 \mu \mathrm{M} \mathrm{B}$ in nutrient solution reduced the total amount of pectin in cell walls and reduced carboxyl groups $\left(\mathrm{COO}^{-}\right)$in the cell walls by $25 \mathrm{nmol}$ per tip. This reduction of negative charges occurs simultaneously with cell wall structural changes, keeping in mind that the formation of the rhamnogalacturonan-II dimer (RGII) from a bridge between $\mathrm{B}$ and two rhamnogalacturonan-II monomers (RG-II) decreases the pore size of the cell wall (HORST et al., 2010). However, Guigues et al. (2014) report that the negative charges on the plasma membrane also contributes to root CEC. Tanada (1995) note that B binds with components of the plasma membrane which can increase the membrane negative charge. However, this effect was probably unimportant in determining the CEC of corn roots, since our results corroborate those of Stass et al. (2007) who studied cell walls. Thus, whereas the majority of $\mathrm{B}$ is associated with plant cell walls, it is likely that the reduction of root CEC had been affected by changes in cell walls. On the other hand, decreases in root $\mathrm{CEC}$ with $\mathrm{Al}$ addition to nutrient solution (Figure 1) was due to the high adsorption strength of this element to root tissue components (HORST et al., 2010).

Differential sensitivity of methods (Figure 1) may have occurred, in part, by the acid pretreatment. In the $\mathrm{KCl} \mathrm{pH} 7$ method (CROOKE, 1964), the acid solution is $0.01 \mathrm{~mol} \mathrm{~L}^{-1}$ (stirring for 5 minutes), whereas the cationic adsorption and
Delta pH 11 methods had acid solutions of 0.05 mol $\mathrm{L}^{-1}$ (stirring for 2 hours), both with $\mathrm{HCl}$. Therefore, use of pre-treatment with the highest $\mathrm{HCl}$ concentration and longer extraction time, probably promoted greater release of cation exchange sites in root tissue that allowed subsequent tests to better express the effects of $\mathrm{B}$ and $\mathrm{Al}$ on CEC of roots. On the other hand, using the sum of cationic nutrients extracted by $\mathrm{HCl}$ solution $0.05 \mathrm{~mol} \mathrm{~L}^{-1}$ provided results similar to the $\mathrm{pH} 7$ method. Besides the effect of pre-treatment, the higher expression of differences in Delta $\mathrm{pH} 11$ was related to the method of calculating root CEC. This calculation considers the concentrations of $\mathrm{H}^{+}$obtained from the $\mathrm{pH}$ value of the solution that varies on a logarithmic scale. However, Meychik and Yermakov (2001) found that three main exchange groups of cations in cell walls (galacturonic acid, carboxylic acids, and phenols) have a dissociation constant $(p K a)$ in $\mathrm{pH}$ less than 10 . Thus, when roots charged with $\mathrm{H}^{+}$are placed in solution with $\mathrm{pH} 11$, deprotonation of these groups can be expected along with acidification of the final solution, which may have contributed to increased differentiation of $\mathrm{B}$ and $\mathrm{Al}$ treatments.

The higher amount of $\mathrm{Fe}$ extracted in roots with low CEC (Table 2) indicates that a reduction in bond strength of this metal. Similarly, Ye et al. (2015) with tomato roots with different degrees of cell wall methylation (> methylation corresponds to $<$ root CEC), found that $\mathrm{Fe}$ was extracted in greater quantities when the level of methylation was high. Overall, the contribution of different cations to the CEC values (cationic extraction method) is 
consistent with concentrations in the nutrient solution. Thus, $\mathrm{Ca}$ showed higher concentration compared to other nutrients (except $\mathrm{K}$ ), consequently, there was a higher concentration extracted from roots that corroborate findings of $\mathrm{Wu}$ and Hendershot (2009). In addition, $K$ showed higher extraction of roots in the absence of $\mathrm{Al}$ and the presence of $50 \mu \mathrm{M} \mathrm{B}$, which did not occur in the presence of $\mathrm{Al}$ (Table 2). Thus, the extraction of $\mathrm{K}$ did not vary with root CEC.

The contents of $\mathrm{Fe}$ and $\mathrm{Cu}$ adsorbed in roots showed greater sensitivity to variations of root CEC than other cations since the decrease in root CEC with addition of $\mathrm{B}$ provide less adsorption in root tissue in the absence or presence of $\mathrm{Al}$ (Table 2). Araújo et al. (2007) also found high Fe adsorption in roots of Paspalum notatum. This result occurs because $\mathrm{Fe}$ is in the trivalent form $\left(\mathrm{Fe}^{3+}\right)$ in solution, however, these authors reported that results varied depending on solutions used and root pre-treatment, and under some conditions $\mathrm{Cu}$ adsorption exceeded that of $\mathrm{Fe}$. However, the amount of cations adsorbed to root tissue suggests that adsorption is preferably different between high and low root CEC values, although concentrations used in the adsorption solution are not the same for $\mathrm{Ca}$ and $\mathrm{Mg}, \mathrm{Fe}, \mathrm{Zn}$, $\mathrm{Cu}$, and $\mathrm{Mn}$. In the treatment without $\mathrm{B}$ and without $\mathrm{Al}$ (higher root CEC) and the treatment with the addition of $200 \mu \mathrm{M}$ of $\mathrm{B}$ and $300 \mu \mathrm{M}$ of $\mathrm{Al}$ (lower root $\mathrm{CEC}$ ) the adsorption order was $\mathrm{Fe}>\mathrm{Ca}>\mathrm{Mg}>\mathrm{Cu}>\mathrm{Mn}>\mathrm{Zn}$ and $\mathrm{Ca}=\mathrm{Mg}>\mathrm{Fe}>\mathrm{Cu}>\mathrm{Zn}>\mathrm{Mn}$, respectively. These results are probably related to factors such as affinity for cations by exchange sites (WU; HENDERSHOT, 2009), cell wall composition (STASS et al., 2007), and CEC variations in the plasma membrane (GUIGUES et al., 2014).

The corn DM decrease with the addition of $\mathrm{Al}$ and the $\mathrm{B}$ failed to decrease this toxicity (Figure 2). Studies have found amelioration of Al toxicity with B application generally occurs using species with a high B demand, like squash (LUBASZEWSKI; BLEVIS, 1996), clover (FAVARETTO et al., 2007), and pea (YU et al., 2009). However, in one of the few studies with grasses, Hossain et al. (2004) reported amelioration of $\mathrm{Al}$ toxicity with the addition of $\mathrm{B}$ in nutrient solution for seedlings of wheat, a species with low B requirements.

The B increase in plants under $\mathrm{Al}$ toxicity is related to DM reduction that may have concentrated the B (Figure 2C-D). However, Wang (2004) reported that corn plants grown under $\mathrm{Al}$ toxicity did not present $\mathrm{B}$ concentration alterations. On the other hand, plants under Al toxicity showed high concentrations of the element, especially in root tissue (Figure 2E-F), due to the strong interaction of Al with root tissue (HORST et al., 2010; DOMINGUES et al., 2016). However, the addition of $\mathrm{B}$ did not change $\mathrm{Al}$ concentration in corn. Similarly, Wang (2004) found no change in Al concentrations with addition of $\mathrm{B}$ in corn. In contrast, some studies have found a decrease in $\mathrm{Al}$ concentrations by adding B (YU et al., 2009), indicating variation between species. Studying bean plants, Stass et al. (2007) found that in cell walls of roots with low CEC, the $\mathrm{Al}$ concentration was lower in roots. However, while in our study B reduced root CEC, there was no change in the $\mathrm{Al}$ concentration in roots. These results indicate that, in our study, the affinity of $\mathrm{Al}$ biomolecules in roots was more important than the change in electrical charges.

Pereira et al. (2008) reported similar effects of $\mathrm{Al}$ on sorghum root systems grown in nutrient solution. The amelioration of $\mathrm{Al}$ toxicity in the root system in response to B addition has been recorded in leguminous plants, particularly for root-growth related attributes (LENOBLE et al., 1996; FAVARETTO et al., 2007). Studying corn plants, Wang (2004) found no amelioration of Al rhizotoxicity with the addition of $\mathrm{B}$ to the nutrient solution. Hossain et al. (2004) observed that in Alsensitive wheat genotypes, the effect of B on root growth was higher than in tolerant genotypes.

The decrease in absorption of nutrients by Al toxicity (Table 4) was mainly due to the negative effects of $\mathrm{Al}$ on the root system and metabolism (HORST et al., 2010; PEREIRA et al., 2008), including transpiration (RUFYIKIRI et al., 2001; BARBOSA et al., 2017). Furthermore, the high concentration of $\mathrm{Al}$ in nutrient solution may also reduced the absorption of nutrients due to competition for cationic sites exchange, absorption to the root cell plasma membranes, and decrease of nutrient activity in solution (WHITE, 2012). On the other hand, the positive B effect at $50 \mu \mathrm{M}$ on the depletion of $\mathrm{Cu}$ may be related to increased demand by plants of this treatment, which also had higher shoot dry matter (Figure 2A).

The correlation between $\mathrm{NH}_{4}{ }^{+}$depletion and transpiration (Figure 3) probably occur because the main ion-root contact mechanism for $\mathrm{NH}_{4}{ }^{+}$(mass flow) was directly affected by transpiration. Other nutrients can also be affected by this mechanism; however, the participation of the diffusion mechanism becomes important, especially for $\mathrm{K}$ and P (MARSCHNER; RENGEL, 2012). However, our study used cultivation with aerated nutrient solutions, thus mass flow mechanism likely gained 
more importance in contributing to the acquisition of nutrients.

York et al. (2015) reported that the higher acquisition capabilities of $\mathrm{N}$ in modern corn hybrids are related to anatomical and architectural attributes of the root system, which may likely affect the absorption of other nutrients (Figure 3). On the other hand, nutrients have different affinities for cationic exchange sites (Table 2) and charged ionic species near the surface are affected by cation distributions (WHITE, 2012). In our study, root CEC had a positive correlation to $\mathrm{Zn}, \mathrm{Cu}$, and $\mathrm{NH}_{4}{ }^{+}$ (especially $\mathrm{Zn}$ ), as correlation occurred in two methods, and $\mathrm{Cu}$ as there was correlation in both tests (Figure 3). Riseman et al. (2005) found increased $\mathrm{Zn}, \mathrm{Cu}$, and $\mathrm{Mg}$ absorption in a Persian Violet genotype with high root CEC, while Cezar et al. (2015) reported correlations between the CEC of roots in oat and $\mathrm{K}$ and $\mathrm{Cu}$ depletion from the nutrient solution.

\section{CONCLUSIONS}

The addition of $\mathrm{B}$ in nutrient solution decreased root $\mathrm{CEC}$, which also occurred when $\mathrm{Al}$ was added. However, $\mathrm{B}$ failed to decrease $\mathrm{Al}$ toxicity in relation to corn growth, Al concentration, nutrient uptake, and transpiration.

The methods used to determine CEC of corn roots had contrasting results, particularly with respect to the effect of $\mathrm{B}$ in the presence of $\mathrm{Al}$. The Delta $\mathrm{pH} 11$ method allows greater differentiation between treatments with the addition of $\mathrm{B}$ and $\mathrm{Al}$ and, in sequence, the cationic adsorption method has the advantage of allowing for the study of the adsorption preference of cations by the roots.

\section{ACKNOWLEDGEMENTS}

The authors would like to thank Ph.D. Stephen A. Prior (USDA-ARS National Soil Dynamics Laboratory) for English corrections of the manuscript. In addition, we thank the National Council for Scientific and Technological Development $(\mathrm{CNPq})$ and Coordination for the Improvement of Higher Education Personnel (Capes).

RESUMO: A maioria dos estudos que registraram amenização da toxidez de Al devido ao decréscimo da capacidade de troca de cátions (CTC) radicular com a aplicação de B foram realizados com espécies eudicotiledôneas (alta CTC radicular). Contudo, o efeito da interação B/Al nos valores de CTC radicular em espécies de baixa CTC radicular, como no milho (Zea mays L.), é pouco conhecido. Assim, os objetivos desse estudo foram: (1) verificar se o B reduz a CTC radicular e se isso beneficia o crescimento e a absorção de nutrientes em plantas de milho sob toxidez por Al; (2) verificar qual método para análise de CTC radicular diferencia melhor o efeito do B e Al. Plântulas de milho foram cultivadas em solução nutritiva completa com os seguintes tratamentos: 0,50 e $200 \mu \mathrm{M}$ de B versus 0 e $300 \mu \mathrm{M}$ de Al. Os atributos radiculares apresentaram correlações com a depleção de nutrientes da solução nutritiva, mas, em geral, a depleção de nutrientes variou principalmente com a transpiração em dois testes de depleção. A adição de B na solução nutritiva reduziu a CTC radicular, o que também ocorreu quando o Al foi adicionado, contudo, o B não aliviou a toxidez por Al nas plantas de milho. Os quatro métodos usados para determinar a CTC radicular do milho tiveram resultados contrastantes, particularmente com relação ao efeito do B na presença de Al.

PALAVRAS-CHAVE: Sorção de metais. Estresse iônico. Atributos radiculares. Métodos de plantas.

\section{REFERENCES}

ARAÚJO, G. C. L.; LEMOS, S. G.; FERREIRA, A. G.; FREITAS, H.; NOGUEIRA, A. R. A. Effect of pretreatment and supporting media on $\mathrm{Ni}(\mathrm{II}), \mathrm{Cu}(\mathrm{II}), \mathrm{Al}(\mathrm{III})$ and $\mathrm{Fe}(\mathrm{III})$ sorption by plant root material. Chemosphere, Amsterdam, v. 68, n. 3, p. 537-545, 2007. https://doi.org/10.1016/j.chemosphere.2006.12.054

BARBOSA, J. Z.; CONSALTER, R.; PAULETTI, V.; VARGAS, A. C. A magnitude da toxidez de B é dependente da condição de acidez do solo. Cultivando o Saber, Cascavel, v. 6, n. 3, 113-121, 2013. https://doi.org/10.5039/agraria.v12i2a5432

BARBOSA, J.Z.; MOTTA, A. C.V.; CONSALTER, R.; PAULETTI, V. Wheat (Triticum aestivum L.) response to boron in contrasting soil acidity conditions. Revista Brasileira de Ciências Agrárias, Recife, v. 12, n. 2, p. 148-157, 2017. 
ÇATAV, Ş. S.; GENÇ, T. O.; OKTAY, M. K.; KÜÇÜKAKYÜZ, K. Effect of boron toxicity on oxidative stress and genotoxicity in wheat (Triticum aestivum L.). Bulletin of Environmental Contamination and Toxicology, Berlin, v. 100, n. 4, p. 502-508, 2018. https://doi.org/10.1007/s00128-018-2292-x

CEZAR, R. M.; BARBOSA, J. Z.; PAULETTI, V. Expressão da capacidade de troca de cátions radicular e nutrição de aveia-preta (Avena strigosa Schreb.) sob deficiência de nutrientes. Científica, Jaboticabal, v.44, n.1, p.83-90, 2015. https://doi.org/10.15361/1984-5529.2016v44n1p83-90

CROOKE, W. M. The measurement of the cation-exchange capacity of plants roots. Plant and Soil, Amsterdam, v. 21, n. 1, p. 43-49, 1964. https://doi.org/10.1007/BF01373871

DOMINGUES, C. R.S.; BARBOSA, J. Z.; CONSALTER, R.; SANTOS, M.; ADAM, W. M.; MOTTA, A. C. $\mathrm{V}$. Influence of zinc deficiency on the mineral composition of maize plants in contrasting soils. Bioscience Journal, Uberlândia, v. 32, n. 5, p. 1234-1245, 2016. https://doi.org/10.14393/BJ-v32n5a2016-32993

FAVARETTO, N.; MOTTA, A. C. V.; BARCIK, C.; LUSTOSA, S. B. C.; COMIN, J. J. Shoot and root responses of Trifolium vesiculosum to boron fertilization in an acidic Brazilian soil. Brazilian Archives of Biology and Technology, Curitiba, v. 50, n. 4, p. 597-604, 2007. https://doi.org/10.1590/S151689132007000400005

GOLDBACH, H. E.; WIMMER, M. A. Boron in plants and animals: Is there a role beyond cell-wall structure? Journal Plant Nutrition and Soil Science, San Francisco, v. 170, n. 1, p. 39-48, 2007. https://doi.org/10.1002/jpln.200625161

GUIGUES, S.; BRAVIN, M. N.; GARNIER, C.; MASION, A.; DOELSCH, E. Isolated cell walls exhibit cation binding properties distinct from those of plants roots. Plant and Soil, Amsterdam, v. 381, n. 1, p. $367-$ 379, 2014. https://doi.org/10.1007/s11104-014-2138-1

HORST, W. J.; WANG, Y.; ETICHA, D. The role of the root apoplast in aluminium-induced inhibition of root elongation and in aluminium resistance of plants: a review. Annals of Botany, Oxford, v. 106, n. 1, p. 185-197, 2010. https://doi.org/10.1093/aob/mcq053

HOSSAIN, A. K. M. Z.; HOSSAIN, M. A.; KOYAMA, H.; HARA, T. Effects of aluminum and boron supply on growth of seedlings among 15 cultivars of wheat (Triticum aestivum L.) grown in Bangladesh. Soil Science and Plant Nutrition, London, v. 50, n. 2, p. 189-195, 2004. https://doi.org/10.1080/00380768.2004.10409271

LENOBLE, M. E.; BLEVINS, D. G.; MILES, R. J. Prevention of aluminum toxicity with supplemental boron. II. Stimulation of root growth in acidic, high aluminum subsoil. Plant, Cell and Environment, New Jersey, v. 19, n. 10, p. 1143-1148, 1996. https://doi.org/10.1111/j.1365-3040.1996.tb00429.x

LUKASZEWSKI, K. M.; BLEVINS, D. G. Root growth inhibition in boron-deficient or aluminum-stressed squash may be a result of impaired ascorbate metabolism. Plant Physiology, Rockville, v. 112, n. 3, p. 11351140, 1996. https://doi.org/10.1104/pp.112.3.1135

KOCHIAN, L. V.; PIÑEROS, M. A.; LIU, J.; MAGALHÃES, J. V. Plant adaptation to acid soils: the molecular basis for crop aluminum resistance. Annual Review of Plant Biology, Palo Alto, v. 66, p. 571-598, 2015. https://doi.org/10.1146/annurev-arplant-043014-114822

MARSCHNER, P.; RENGEL, Z. Nutrient availability in soils. In: MARSCHNER, P. (Ed.). Marschner's mineral nutrition of higher plants. 3. ed. San Diego: Elsevier, 2012, p. 315-330.

https://doi.org/10.1016/B978-0-12-384905-2.00012-1

MARTINS, A. P. L.; REISSMANN, C. B. Material vegetal e as rotinas laboratoriais nos procedimentos químico-analíticos. Scientia Agraria, Curitiba, v. 8, n. 1, p. 1-17, 2007. https://doi.org/10.5380/rsa.v8i1.8336 
MEYCHIK, N. R.; YERMAKOV, I. P. Ion exchange properties of plant root cell walls. Plant and Soil, Amsterdam, v. 234, n. 2, p. 181-193, 2001. https://doi.org/10.1023/A:1017936318435

PERREIRA, J. M.; CAMBRAIA, J.; FONSECA JÚNIOR, E. M.; RIBEIRO, C. Efeito do alumínio sobre a absorção, o acúmulo e o fracionamento do fósforo em sorgo. Bragantia, Campinas, v. 67, n. 4, p. 961-967, 2008. https://doi.org/10.1590/S0006-87052008000400019

RIAZ, M.; YAN, L.; WU, X.; HUSSAIN, S.; AZIZ, O.; WANG, Y.; INRAN, M.; JIANG, C. Boron alleviates the aluminum toxicity in trifoliate orange by regulating antioxidant defense system and reducing root cell injury. Journal of Environmental Management, Berlin, v. 208, p. 149-158, 2018.

https://doi.org/10.1016/j.jenvman.2017.12.008

RISEMAN, A.; CRAIG, R.; LYNCH, J. P. Zinc uptake and shoot partitioning between zinc efficient and inefficient exacum genotypes. Journal of the American Society for Horticultural Science, Alexandria, v. 130, n. 5, 674-679, 2005.

RUFYIKIRI, G.; DUFEY, J. E.; NOOTENS, D.; DELVAUX, B. Effect of aluminium on bananas (Musa spp.) cultivated in acid solutions. II. Water and nutrient uptake. Fruits, Cambridge, v. 56, n. 5, p. 5-16, 2001. https://doi.org/10.1051/fruits:2001107

STASS, A.; KOTUR, Z.; HORST, W. J. Effect of boron on the expression of aluminium toxicity in Phaseolus vulgaris. Physiologia Plantarum, Lund, v. 131, n. 2, p. 283-290, 2007. https://doi.org/10.1111/j.13993054.2007.00957.x

TANADA, T. Boron as a transducer in some physiological processes of plants. Journal of Plant Nutrition, London, v. 18, n. 9, p. 1743-1750, 1995. https://doi.org/10.1080/01904169509365020

WANG, Y. The role of silicon, boron and pH-dependent aluminium speciation in solution on aluminum toxicity in maize (Zea mays L.). 2004, 101 f. Thesis (Doctorate in Horticulture Science)- University Hannover, Germany, 2004.

WHITE, P. J. Ion uptake mechanisms of individual cells and roots: short-distance transport. In: MARSCHNER, P. (ed.). Marschner's mineral nutrition of higher plants. 3. ed. San Diego: Elsevier, 2012, p. 7-47. https://doi.org/10.1016/B978-0-12-384905-2.00002-9

WU, Y.; HENDERSHOT, W. H. Cation exchange capacity and proton binding properties of pea (Pisum sativum L.) roots. Water, Air and Soil Pollution, Norwell, v. 200, n. 1, p. 353-369, 2009.

https://doi.org/10.1007/s11270-008-9918-2

YE, Y. Q.; JIN, C. W.; FAN, S. K.; MAO, Q. Q.; SUN, C. L.; YU, Y.; LIN, X. Y. Elevation of NO production increases Fe immobilization in the Fe-deficiency roots apoplast by decreasing pectin methylation of cell wall. Scientific Reports, London, n. 5, article 10746, 2015. Available in: < http://www.ncbi.nlm.nih.gov/pmc/articles/PMC4466582/>. Access in: 29 November 2016.

YORK, L. M.; GALINDO-CASTANEDA, T.; SCHUSSLER, J. R.; LYNCH, J. P. Evolution of US maize (Zea mays L.) root architectural and anatomical phenes over the past 100 years corresponds to increased tolerance of nitrogen stress. Journal of Experimental Botany, Oxford, v. 66, n. 8, p. 2347-2358, 2015.

https://doi.org/10.1093/jxb/erv074

YU, M.; SHEN, R.; XIAO, H.; XU, M.; WANG, H.; WANG, H.; ZENG, Q.; BIAN, J. Boron alleviates aluminum toxicity in pea (Pisum sativum). Plant and Soil, Amsterdam, v. 314, n. 1, p. 87-98, 2009.

https://doi.org/10.1007/s11104-008-9708-z 